\title{
AFFECTIVE AND MOTIVATIONAL FACTORS IN ENGLISH AS A SECOND LANGUAGE IN SPAIN
}

\author{
MARTA GARCÍA-SAMPEDRO \\ Department of Education Sciences \\ University of Oviedo \\ Oviedo 33005, Spain \\ E- mail address: garciafmarta@uniovi.es \\ ORCID number: http://ordic.org//0000-0003-1523-1314 \\ SUSANA AGUdo PRADO \\ Department of Education Sciences \\ University of Oviedo \\ Oviedo 33005, Spain \\ E- mail address: agudosusana@uniovi.es \\ ORCID number: http://ordic.org//0000-0002-7120-6810
}

\begin{abstract}
Aim. Due to the disappointing results in English oral competence achieved by Spanish students in international and national evaluations, the main aim of this research is to establish teachers perceptions on the importance of affective factors and motivation in teaching and learning English in primary and secondary education. It is also essential to decide whether these factors help students to improve their oral skills.

Method. A qualitative paradigm was utilised in this research in which three focus groups with ten teachers each and a moderator were organised in two different Teacher Training Faculties (Spain and the United Kingdom). The categories of analysis were previously established according to the research aims.

Results and conclusion. The results obtained through the analysis of categories indicated that the participant teachers consider affective factors and motivation as fundamental aspects in the process of teaching and learning a second language. In addition, they agreed with prestigious experts on the matter, such as Dörnyei, Ushioda or Chomsky, that these aspects are crucial to improve students' linguistic oral competence. The teachers demonstrate their opinions based on their professional experiences and educational philosophy constituting altogether a valuable bunch of information for other experts and researchers.
\end{abstract}

Keyword: affective factors, motivation, English as a second language teaching

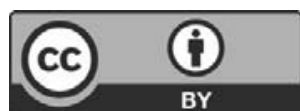




\section{INTRODUCTION}

$\mathrm{T}$ The Common European Framework of Reference for Languages (CEFRL) and its competence approach should have already been incorporated to the teaching and learning of languages in Spain. However, national and international evaluations on the students' skills in foreign languages do not show the good results that could be expected (Bonnet, 2002; Ministerio de Educación, Cultura y Deporte, 2012; Cambridge Monitor, 2017). Spain is below the average levels desired by the European Commission regarding the primary and secondary students' development in oral comprehension and linguistic competence.

Some of the reasons are that the films and series shown on national televisions and cinemas are dubbed into Spanish, which does not help at all (Vez, Martínez Piñeiro, \& Lorenzo Rodríguez, 2013) and obviously, it can be said that English oral skills are not sufficiently and efficiently trained in primary and secondary schools.

Due to these facts, the authors of this article have focused on the importance of affective factors in the acquisition of second languages and have designed a research whose main aim is to know English language teachers' and experts' perceptions on the matter. It has also intended to discover if these factors help students improve their oral communicative skills in the second language and, if so, in what way. Another aim of the research is to inspect which methodologies, resources, materials and assessment tools are advisable and recommendable to increase students' motivation. From a neuronal perspective, affect is a fundamental element of cognition, and due to this fact, motivation and learning are deeply connected concepts (Schumann, 1994). Affect refers to the feelings people experience as part of their lives and includes both moods and emotions. At the same time, it helps people integrate successfully with others (Schumann, 2000). Affective factors and motivation are significant aspects in the acquisition and ideal development of the linguistic and communicative competence in a foreign language.

There are many studies on the influence of affective factors and motivation throughout the teaching-learning process of the oral language. Principally, the most influential causes in this process, both in a positive or negative way, are affection, emotions, anxiety and motivation (Dörnyei, 2001, 2001a). In this sense, Thomas Scovel (2000) points out that emotions may well be the cause that most influences language learning. He also notes that affective variables are commonly the least understood by researchers. This may be partly because of the fact that most research in the field of learning is of quantitative nature and affective factors are not quantitatively measurable with ease. Peter D. MacIntyre and Robert C. Gardner (1972) and Begona Ibarrola (2013) believe that emotions are fundamental to the teaching-learning process, and therefore, it is necessary to produce a pleasant emotional climate in the classrooms in order to understand and manage students' feelings.

Jane Arnold $(2000,2009)$ also acknowledges the importance of affective factors in language teaching-learning and explains that this is not a new certainty. In 
the fifth century St. Augustine wrote about his unpleasant educational experiences as a child when he had to learn Greek. He described how curiosity and interest, rather than pressure and fear, were what led him to a successful learning.

Much more recently, in the 1970s, educational approaches such as Suggestopedia, Silent Way, Community Language Learning or Total Physical Response took into account the role that affectivity plays in language learning. In turn, the concept of student-centred teaching also connects with the theme of affection in the classroom, as Krashen's affective filter metaphor does (Arnold, 2009).

Nowadays, affection is more relevant in the teaching of second languages than it has ever before; for example, in Europe, the Common European Framework of Reference for Languages: Learning, Teaching and Evaluation (CEFR) includes, among the competences involved in language learning, the existential competence, which is composed of elements related to affection. According to this document, affectivity influences language learners and users in their communicative acts and their ability to learn. It could be said that emotions are the most influential factor in the language learning process and the least studied by researchers. In contrast, some people experience anxiety, in some of its manifestations (tension, apprehension, nervousness, worry, cold sweat or nausea) when learning a new language. Anxiety is defined as the subjective feeling that produces all these alterations. Often, it is inevitable and its effects alter the way humans behave. Therefore, anxiety is an affective factor that negatively impacts learning and due to it, the process of learning a second language can be stressful for many students (MacIntyre, 2002; Goh \& Burns, 2012).

Elaine K. Horwitz, Michael B. Horwitz \& Joann Cop (1986) believed that linguistic anxiety is a compound of self-perceptions, beliefs, feelings and behaviour related to the learning process, which arise from a specific speech situation. P. D. MacIntyre and R. C. Gardner (1991) explained that not all individuals suffer from anxiety of the same stimuli. Besides, anxiety can alter the language learning process, affect cognitive functioning and disrupt memory in language use and learning. Elaine M. Phillips (1992) stated that linguistic anxiety is associated with oral production at times with high levels of psychological pressure, such as oral exams or interviews. Being aware of this reality, teachers may use an approach to develop oral production activities and avoid possible awkward situations for learners.

H. Douglas Brown (1994) agrees with the previous authors that anxiety is a very decisive affective variable in the acquisition of a second language and is intrinsically related to other feelings such as self-esteem, inhibition, decision making and taking risks.

Returning to P. D. MacIntyre and R. C. Gardner (1994), learners who suffer from anxiety perceive speaking in a second language as an uncomfortable experience because they are not prepared to make mistakes. As a result of social pressure, students are often afraid of making mistakes and experiencing new modes of expression in the new language, so they do not take any risks. All these concerns make their cognitive performance less efficient. 
On the other hand, motivation is also a fundamental aspect in the process of learning a second language (Lasagabaster, Doiz, \& Sierra, 2014). It is considered essential in educational terms on behalf of students who need to gain control of their own learning and success at the same time (Dörnyei \& Kubanyiova, 2014).

Ema Ushioda $(2003,2012)$ agrees with these and with the previous authors that motivation is a variable of recognised importance in language learning that is reflected in the objectives, in the levels of effort invested, in the depth of the commitment and in the degree of persistence in learning. He also argues that while theoretical concepts regarding motivation for language learning have changed and evolved in the last fifty years, all of them seek to describe and analyse the reasons why people learn or do not want to learn a language and to what extent they strive in the effort and succeed.

Students' motivation depends substantially on the evaluations people make of the language learning situation according to five aspects related to the task: it is novel (but also familiar); it produces pleasure; it is adequate to the interests of the student and his/her objectives; it is something that he/she can handle and it is compatible with his/her self-image and socio-cultural rules (Schumann, 2000).

It should be said that both teachers and students' s motivation is generally very strong at the beginning but decreases throughout the learning process. This may happen during a course or in the short space of a single lesson due to many internal and external influences. Once the novelty of learning a language declines, motivation tends to descend, especially if the cognitive and linguistic demands of the process of learning increase. Thus, a fundamental aspect for teachers is not only to unleash the enthusiasm and initial interest, but more importantly to maintain motivation all throughout the language learning process (Gardner, Masgoret, Tenant, \& Mihic, 2004).

Bearing in mind the importance of affective factors and motivation in the process of learning a second language, a qualitative research has been designed with the aim of knowing teachers' perceptions on the importance of affective factors and motivation in primary and secondary education. It is also fundamental to know whether these factors help students to improve their oral skills or not.

\section{METHODS}

\section{Participants}

The participants in this study were thirty experts in English as a foreign language (primary teachers, secondary teachers and university teachers and professors) who resided both in Spain and the United Kingdom and were selected through a sample for convenience because of their implication either in educational innovation, or in the study of the English language teaching as a second language. 


\section{Research Instrument and procedure}

The research was substantiated on the qualitative paradigm, being focus groups the technique used to collect data. Three focus groups were organised with ten participants each and a moderator. The discussion lasted approximately for two hours. The first two focus groups were developed in a Teacher Training Faculty in Spain and the third group was carried out in the United Kingdom. In order to present the research to the participant teachers, they were called by telephone and then, an informative email was sent to them. Teachers were chosen for many professional reasons: their educational innovative practices, their experience in international collaborative projects, their research on this field of study, etc.

The three discussion groups were different in nature and membership and the results obtained were highly representative.

Focus group No. 1 was made up of ten (English as a Second Language) teachers from primary and secondary schools. All of them were selected for their commitment to educational innovation and the promotion of oral communication in English. They worked for private schools, state schools and semi-private schools (these schools are led by private companies although their staff members are paid by the government).

To begin the discussion session, some examples of educational projects and good practice experiences were briefly presented. Subsequently, they started a discussion on affective factors and motivation in the English classroom. The discussion was recorded with a tablet (audio) and the moderator took some notes about some relevant aspects.

Focus group No. 2 was composed by ten university teachers and professors from a Teacher Training Faculty in Spain. All of them were chosen because of their involvement in Language Teaching Training programmes. The procedure was similar to Focus group No. 1 and it was developed one week after the first.

Focus group No. 3 comprised ten university teachers and professors, experts in Teaching English as a Second Language and Teacher Training Programmes at a Teacher Training faculty in the UK. This third focus group was organised during a research visit carried out in 2018. This visit had the aim of deepening in educational aspects related to the importance of affective factors and the promotion of oral communication in English as a second language. Continuing with the research started in Spain, the opportunity of organising this third focus group contributed to enrich the study including the opinions and experiences of these experts on the matter.

This focus group was organised two months after the first and the second. It was shorter than the others and it took only an hour and a half.

\section{Data Analysis}

The categories of analysis were established previously with the intention of knowing the management and motivational strategies that participant teachers used and their perceptions and opinions on the issue. These categories were: Oral communication (English), Methodology, Resources and Materials, and 
Motivation. During the process, a new category arose. This was the case of Assessment of the oral skills. All the information recorded was transcribed and the data was classified into categories.

\section{RESULTS}

In order to facilitate the reading and understanding of the results obtained, these are presented in general categories, independently which focus groups were retrieved from. In these category sections, teachers' opinions are explained in detail.

\section{Oral communication}

All the participant teachers consider that oral communication activities are usually highly motivating for children, especially, in primary education because pupils do not feel anxious or afraid of speaking in front of an audience. In order to promote oral communication, children at schools must be provided with opportunities and experiences to speak in English.

It is not the same in the case of secondary students because many of them are afraid of making mistakes. When they have to do an oral activity in the classroom some of them avoid participating since they think they are wasting their time since the situation is not real. Sometimes they feel stressed or anxious because they have to speak in English in front of their mates. Nevertheless, they are truly interested in having real and authentic conversations when they have got a native conversation assistant at school or when they can communicate with students from other countries through video conference, international meetings or exchanges. In these situations, they make an effort to carry out their tasks successfully. Though they can feel a bit of embarrassment, they do their best to communicate with others or to solve a classroom situation that it is important for them.

On the other hand, secondary teachers think that they should give students the opportunity to choose the topics for the oral activities and decide how to present them in the classroom as this will increase their interest and motivation.

Both primary and secondary teachers agree to say that English speaking level in Spain has increased substantially in the last few years through the bilingual programmes started in many (private and state) schools since the year 2000. Besides, nowadays English can be found everywhere, in advertising, songs, computer games, videos, etc. and students can communicate with people from different parts of the world thanks to internet. Considering that the language used for this global communication is English students have more reasons to learn it and consequently to feel more motivated.

\section{Methodology}

One of the teachers refers to the importance of methodology to improve students' motivation. He assesses that if teachers implement alternative ways 
of teaching, such as Task Based Learning or Project Based Learning, students will be more encouraged and their oral skills will be more productive.

In pre-school and primary education, pupils are much more motivated and enthusiastic with English lessons. They can play and sing and learn at the same time. Grammar structures and vocabulary are learned through reading and listening to stories, watching videos or singing songs what is a real advance in many cases. It is true that methodologies have enhanced and changed a lot in many schools (but not in every school). As a consequence, children improve their abilities to communicate in English while enjoying it, which is a relevant achievement.

On the other hand, trying to change traditional English teachers' mentality is a challenge for most of the participants who are familiar with new methodologies and innovative techniques. They are aware of the necessity of enriching teaching speaking in Spain and obviously, students' and teachers' motivation, bearing in mind the disappointing results obtained in the national and international evaluations mentioned before.

\section{Resources and materials}

The use of attractive resources and materials was also discussed in the groups. It should be remembered that all the teachers and professors involved in this research were selected because of their compromise with innovation in English as a second language teaching and their participation in many different innovative and research projects.

Due to these reasons, it is easy to understand why all the participant school teachers agree with the idea of using some other resources apart from course books. They all state that they could work without a coursebook but unfortunately they cannot do it at the moment since these are imposed by schools and their use is compulsory for the time being. Course books, are considered a mechanical and not very motivational resource by all the participant teachers. All of them are in favour of using other resources and more innovative methods. In their opinion, coursebooks limit teacher's freedom and restrict the possibilities of communicating orally in the classroom. For all these reasons, all the teachers consider course books as a boring and tough resource with low positive effects.

In the lower grades of primary school, the implementation of routines and the daily use of songs, stories and games help children increase their interest and motivation and their oral communicative competence gradually. However, course books are still present in most secondary education. It is very difficult to avoid with the use of course books because many teachers and parents consider that they are indispensable to prepare students for the access exams to university and for the national and international English language qualifications exams.

Despite all this, participants remark that there are some teachers who manage to work through tasks or projects involving students in their learning and promote autonomous skills, thus obtaining highly motivated students and 
very good results in the above mentioned exams; they should be an example to follow.

On the other hand, the use of ICT at schools is increasing gradually. They are being implemented at schools or at homes, as homework, providing useful and attractive resources. However, participant teachers insist on the idea of employing ICT in a creative and responsible way and students have to learn how to use them. ICT allow students to watch, listen or play and improve their linguistic competence in English. As some ICT devices, such as television, laptops, consoles, tablets and mobile phones are available in many homes, children are able to practice another language just in a click, watching their favourite cartoons or movies and playing games. It is important to remark on the importance of ICT as motivational resources. Pupils and students love using technology and they appreciate it massively when it is implemented at school.

\section{Assessment of the oral skills}

All the participant teachers agree that oral skills should be assessed at any level of education. They also state that traditional oral tests, in which only errors are counted, should be avoided because they produce frustration among the pupils and students and do not help them improve their motivation and their learning. In contrast, other types of assessment, such as self-assessment or peer-assessment, should be adopted and teachers should attach more importance to observation and to the use of alternative tools such as rubrics.

Finally, participant teachers acknowledge the necessity of including English language oral exams in the access tests to universities. This way, English oral practice should be normalized at primary and secondary schools and students should be more interested and motivated during their English lessons.

\section{Students' motivation and Teacher's motivation}

Teachers insist on the necessity of motivating students with engaging activities and projects. New approaches promote a change in the school roles. Students should become the centre of the learning processes and teachers should become guides. They also foster cross-curricular projects, tasks or activities involving areas such as art, music, ICT or sciences. Cooperation among students is also considered fundamental. Learning should be significant for students in order to have more motivated students. When students are motivated, they enjoy English lessons more intensely and their competences improve extraordinarily. Furthermore, learning is memorable and meaningful and, therefore, their taste for learning improves progressively.

All the participant teachers feel deeply motivated, especially when implementing their projects and seeing their students' progress and commitment. Furthermore, they realise the more motivated they feel, the more engaged their students are. 


\section{CONCLUSIONS}

This research was initiated in response to the reality in which English oral teaching in Spain is immersed. On the one hand, Spain experiences discouraging results obtained by Spanish students in their oral skills performance in international and national evaluations (Vez, Martínez Piñeiro, \& Lorenzo Rodríguez, 2013). On the other hand, teaching languages is changing in Spain and there are a lot of teachers who foster new forms of teaching with the aim of improving the teaching and learning process and promote students' motivation.

All the participant teachers consider that affective factors and motivation are essential in the teaching and learning processes of languages and outline some of the most remarkable perceptions acquired through their professional experience. They recognise that although Spanish students' oral English skills results have been rather low in international and national evaluations, the improvement in the last few years is considerable due to the implementation of the Bilingual Programmes at schools and the increase of hours dedicated to teach English or in English. The presence of conversation assistants at schools helps the promotion of students' oral skills and the reinforcement of their motivation. In the same way, it happens with school exchanges and participation in the projects with foreign schools, which benefit students considerably. Students make a real effort because they have the necessity of communicating in English and consequently they consider this learning more authentic.

Besides, teachers insist on the importance of adopting communicative approaches in the English language and in bilingual classrooms. Methodologies such as Project Based Learning, Task Based Learning or CLIL are recommended. Similarly, any other way of working that fosters cooperative and autonomous learning, cross-curricular topics, changes in the classroom roles, and definitely, an increase and improvement of students' motivation.

Incorporating new resources and materials to reinforce oral production in the English classroom is advisable and also, to integrate ICT in the English classroom, including m-learning (learning through mobile devices).

The promotion of the watching and listening of TV or radio programmes, videos or games in the English language is perceived as an optimal practice to be done at home, as homework. And lastly, teachers recommend incorporating or changing the sort of assessment employed for the oral skills which have not been evaluated traditionally, or if so, they have been assessed attending only to the number of mistakes made by students. In conclusion, teachers maintain the desire of transforming the English language teaching in Spain. To achieve this goal, they are working to improve students' motivation and to adapt English teaching to the 21st century demands, which is more urgent than ever.

Teachers' level of enthusiasm and commitment is one of the most important factors that can affect students' motivation to learn. If a teacher is motivated to teach, there are many possibilities for students to be motivated to learn (Dörnyei \& Ushioda, 2011). 


\section{REFERENCES}

[1] Arnold, J. (2000). La dimensión afectiva en el aprendizaje de idiomas. Madrid: Cambridge University Press.

[2] Arnold, J. (2009). Affect in L2 learning and teaching. Ella, Estudios de lingüística inglesa aplicada, 9, 145-151.

[3] Bonnet, G. (Ed.) (2002). The assessment of pupil's skills in English in eight countries. Retrieved May 15, 2020 from http://www.mecd.gob.es/dctm/ievaluacion/internacional/habilidadesingles2002.pdf?documentId=0901e72b8011054e

[4] Brown, H. D. (1994). Principles of language learning and teaching. Englewood Cliffs, NJ: Prentice Hall.

[5] Cambridge Monitor. (2017). Europa ante el espejo. Retrieved May 15, 2020 from https:/ / www. cambridge.es/nosotros/cambridge-monitor/europa-ante-el-espejo

[6] Council of Europe. (2001). Common European Framework of Reference for Languages: Learning, teaching, assessment. Retrieved May 15, 2020 from https://www.coe.int/en/web/portfolio/ the-common-european-framework-of-reference-for-languages-learning-teaching-assessment-cefr.

[7] Dörnyei, Z., \& Kubanyiova, M. (2014). Motivating learners, motivating teachers: Building vision in the language classroom. Cambridge: Cambridge University Press.

[8] Dörnyei, Z., \& Ushioda, E. (2011). Teaching and researching motivation ( $2^{\text {nd }}$ Ed.). Harlow: Longman.

[9] Dörnyei, Z. (2001). Teaching and researching motivation. Harlow: Longman.

[10] Dörnyei, Z. (2001a). Motivational strategies in the language classroom. Cambridge: Cambridge University Press.

[11] Gardner, R. C., \& Lambert, W. E. (1972). Attitudes and motivation in second language learning. Rowley (MA): Newbury House.

[12] Gardner, R. C., Masgoret, A. M., Tenant, J., \& Mihic, L. (2004). Integrative motivation: Changes during a year-long intermediate-level language course. Language learning, 54, 1-34.

[13] Goh, C., \& Burns, A. (2012). Teaching Speaking. Cambridge: Cambridge University Press.

[14] Horwitz, E. K., Horwitz, M. B., \& Cope, J. (1986). Foreign language classroom anxiety. The Modern Language Journal, 70 (2), 125-132.

[15] Ibarrola, B. (2013). Aprendizaje emocionante. Neurociencia para el aula. Madrid: SM.

[16] Lasagabaster, D., Doiz, A., \& Sierra, J. M. (Eds.). (2014). Motivation and Foreign Language Learning: From Theory to Practice. Amsterdam: John Benjamins Publishing Company.

[17] MacIntyre, P. D., \& Gardner, R.C. (1991). Methods and results in the study of anxiety and language learning: A review of the literature, Language Learning, 41 (1), 85-117.

[18] MacIntyre, P. D., \& Gardner, R. C. (1994). The language effects of language anxiety on cognitive processing in the second language., Language Learning, 44 (2), 283-305.

[19] MacIntyre, P. D. (2002). Motivation, anxiety and emotion in second language acquisition. In: P. Robinson (Ed.), Individual differences and instructed language learning (pp. 45-68). Amsterdam: John Benjamins.

[20] Ministerio de Educación, Cultura y Deporte. (2012). Estudio Europeo de Competencia Lingüística (EECL). Volumen I. Informe español Ministerio de Educación, Cultura y Deporte. Madrid. Retrieved May 15, 2020 from https://www.educacionyfp.gob.es/inee/evaluaciones-internacionales/ otros-estudios/estudio-europeo.html

[21] Phillips, E. M. (1992). The effects of language anxiety on students oral test performance and attitudes. The Modern Language Journal, 76, (1), 14-26.

[22] Schumann, J. (1994). Where is cognition? Emotion and cognition in second language learning. Studies in second language learning acquisition, 16, 231-242.

[23] Schumann, J. (2000). Perspectiva neurobiológica sobre la afectividad y la metodología en el aprendizaje de segundas lenguas. In: J. Arnold (Ed.), La dimensión afectiva en el aprendizaje de lenguas (pp. 49-62). Madrid: Cambridge University Press.

[24] Scovel, T. (2000). Learning New Languages: A Guide to Second Language Acquisition. Boston: Heinle \& Heinle.

[25] Ushioda, E. (2003). Motivation as a social mediated process. In: D. Little, J. Ridley, \& E. Ushioda (Eds.), Learner autonomy in the foreign language classroom: Teacher, learner, curriculum and assessment (pp. 90-102). Dublin: Authentic. 
[26] Ushioda, M. (2012). Motivation. In: A. Burns, \& J. C. Richards (Eds.), Pedagogy and practice in Second Language Learning (pp. 77-85). Cambridge: Cambridge University Press.

[27] Vez, J. M., Martínez Piñeiro, E., Lorenzo Rodríguez, A. (2013). Determining factors of the academic performance on "listening" of Spanish students of EFL. Results from the ESLC. Porta Linguarum, 20, 57-76. 